\title{
Language Access Services for Latinos with Limited English Proficiency: Lessons Learned from Hablamos Juntos
}

\author{
Shinyi Wu, $P h D^{7}$, M. Susan Ridgely, $J D^{7}$, José J. Escarce, $M D, P h D^{1,2}$, \\ and Leo S. Morales, MD, PhD ${ }^{1,2}$
}

${ }^{1}$ RAND Corporation, P.O. Box 2138, Santa Monica, CA 90407-2138, USA; 2 Division of General Internal Medicine and Health Services Research, Department of Medicine David Geffen School of Medicine at the University of California, Los Angeles, CA, USA.

\begin{abstract}
BACKGROUND: The Robert Wood Johnson Foundation funded Hablamos Juntos (HJ), a \$10-million multiyear demonstration to improve access to health care for Latinos with limited English proficiency and to explore cost-effective ways for health care organizations to provide language access services.
\end{abstract}

HABLAMOS JUNTOS: In this manuscript, the authors draw on their experiences in evaluating HJ, provide brief descriptions of innovative interventions, estimate operating costs, and synthesize lessons learned about implementation. A number of barriers and facilitators are documented.

CONCLUSION: The experience of HJ grantees provides guidance for organizations contemplating similar efforts. In particular, it highlights the need for health care organizations to involve physicians in the design and adoption of language services.

KEY WORDS: health services accessibility; language services; Spanish; delivery of health care; health policy; cost.

$\mathrm{J}$ Gen Intern Med 22(Suppl 2):350-5

DOI: $10.1007 / \mathrm{s} 11606-007-0323-0$

(c) Society of General Internal Medicine 2007

$\mathrm{B}$ etween 1990 and 2000, the number of Latin American immigrants in the United States rose from 8.4 to 16.1 million. ${ }^{1,2}$ The rapid influx of these immigrants was accompanied by their geographic dispersion throughout the United States, including several states in the South and Midwest. ${ }^{3}$ Because nearly half of these immigrants do not speak English well, ${ }^{4}$ health care providers throughout the country have been faced, some for the first time, with treating large numbers of patients with limited English proficiency (LEP).

Language barriers can have a significant adverse impact on health and health care including lower health status; ${ }^{5,6}$ lower likelihood of having a usual source of care; ${ }^{5-7}$ lower rates of receipt of preventive health services; ${ }^{8,9}$ increased risk of drug complications; ${ }^{10}$ and greater resource utilization for diagnostic testing. ${ }^{11}$ Spanish-speaking patients and Spanishspeaking parents of pediatric patients report lower satisfaction with care, worse communication with their providers, worse access to care, and worse customer service from managed care organizations compared to their English-speaking counterparts. ${ }^{12-14}$

Research suggests that the provision of trained professional interpreters or bilingual providers, in contrast to no language services or use of ad hoc interpreters (such as family members, friends, and untrained medical or nonmedical staff), can improve quality of care for LEP patients. ${ }^{15}$ Title VI of the Civil Rights Act of 1964 requires that organizations receiving federal support ensure that LEP individuals have meaningful access to services. ${ }^{16}$ Implementation of this mandate, however, has been hampered by a number of factors, including a lack of research to inform health care providers about how best to provide language services to LEP patients. ${ }^{17}$

In this manuscript, we provide brief descriptions of ten innovative projects to reduce language barriers, drawing on our experiences in evaluating Hablamos Juntos (HJ), a national initiative funded by the Robert Wood Johnson Foundation (RWJF) to improve access to quality health care for Latino patients with LEP. ${ }^{18}$ We also provide estimates of the operating costs of these programs and synthesize lessons learned about implementation of the interventions.

\section{THE HABLAMOS JUNTOS NATIONAL DEMONSTRATION AND EVALUATION}

In 2002, RWJF launched the HJ national demonstration (http:// www.hablamosjuntos.org/) to develop affordable models for health care organizations to offer language access services to Latino patients with LEP. The demonstration provided grants of up to $\$ 1$ million to 10 organizations in communities with new and rapidly growing Latino populations.

There were 3 main areas of required activities pertaining to language services as set out by the National Program Office (NPO) for the HJ demonstration. First, sites were required to plan and carry out activities related to the recruitment, assessment, training, and placement of medical interpreters at key access points in their health care systems. Second, sites were required to develop activities to create an environment and culture supportive of interpretation, such as developing institutional leadership, recruiting physician champions, and providing payment for medical interpretation services. Third, sites were asked to beta test an assessment of language proficiency and develop comprehensive training programs for interpreters. In addition, some sites also put resources into translation and development of new Spanish language materials, and supported the NPO's efforts to develop universal way-finding symbols for hospitals and clinics.

The Foundation and the NPO purposefully selected a diverse group of organizations for this demonstration, each with a 
distinct approach to addressing language access in their communities. This seemed prudent at the time (2002) given the lack of an evidence base to suggest that any one approach or model would be superior to another.

RWJF also provided grants to the RAND Corporation to conduct a cross-site evaluation of the HJ demonstration. Briefly, the goals of the evaluation were to provide sufficiently detailed descriptions of the interventions, their implementation, and operating costs; to enhance the likelihood of replication at other sites; and to show the impact of the interventions on patient-centered outcomes of care. The methods and detailed findings from the evaluation are reported elsewhere. ${ }^{18}$ Below we briefly describe the interventions and discuss lessons learned from the evaluation, focusing on the costs, barriers, and facilitators of implementation. These observations are drawn from a multisite case study in which we collected and analyzed descriptive information from key informant interviews with a broad range of $\mathrm{HJ}$ project stakeholders in each of the 10 HJ sites, and from a cost study in which we collected cost information from project directors in $8 \mathrm{HJ}$ sites. (Two sites did not participate in the cost study.)

\section{HJ INTERVENTIONS TO PROVIDE LANGUAGE ACCESS SERVICES}

A summary of the $10 \mathrm{HJ}$ projects appears in the Table 1 . The grantee organizations included 4 hospital systems, 2 Medicaid health maintenance organizations (HMO), 1 area health education center (AHEC), 1 school of public health, and 2 community organizations. All but 2 of the HJ demonstration projects provided language access services in clinical health care settings, most commonly in emergency departments (EDs) and obstetric/gynecology units, which are critical access points for Latino patients.

In the majority of the study sites, the primary intervention was increasing the availability of medical interpreters. Three hospitals hired, trained, and certified additional professional interpreters and redeployed interpreters in response to system and patient care demands (sites 4, 6, and 7). Two of these hospitals also offered financial incentives (salary increase or bonus) to bilingual staff to encourage them to be assessed for language proficiency and to receive interpreter training. One of the hospital systems developed an innovative model, called the Patient Navigator, to allow interpreters to accompany patients between clinical departments (e.g., ED and radiology), rather than restricting the interpreters to a single unit, to enhance continuity within an episode of care (e.g., an ED visit). Two grantees collaborated with local partners to establish language service agencies (sites 1 and 9). These agencies recruited, trained, and deployed their interpreters to the participating health care facilities. They provided quality control and charged health care organizations a nominal fee for service.

One of the participating Medicaid HMO grantees encouraged the use of interpreters by reimbursing interpreter services (site 2). The other Medicaid HMO enhanced its existing member call center with a bilingual nurse advice line providing interpretation, patient referral, and support 24 hours a day (site 3). The AHEC grantee, which was located in a rural area with widely dispersed patients and providers, purchased equipment, wiring, and routers for its partnering hospitals and provided video medical interpretation via high-speed telecommunication links with the hospitals (site 5). The School of Public Health grantee developed a masters degree program in medical interpreting and health applied linguistics that included internship rotations in health care facilities (site 10). The final site, another community organization serving a mostly rural area, focused on advocacy for policy change at the state and local levels. They provided assistance to local health care providers as well as direct language assistance to clients applying for public benefits (site 8). Most sites fulfilled the HJ interpreter training requirement by collaborating with local educational institutions to develop college-level interpreter training programs.

\section{THE ANNUAL OPERATING COSTS OF HJ INTERVENTIONS}

We defined operating costs of the $\mathrm{HJ}$ interventions as the dollar value of the resources (including labor, contracts, equipment, materials, and supplies) used by the grantee and all major partners. Costs were assessed for 1 year from October 2004 to September 2005, which corresponds to the second, and last, year of the HJ demonstration. By that point all sites had implemented their interventions. Our cost analysis methodology is described elsewhere. ${ }^{18}$

On average, the annual costs of operating the $\mathrm{HJ}$ interventions were $\$ 666,000$ per site, with a range of $\$ 324,000$ to $\$ 1,181,000$ (see Table 1). The HJ sites that provided interpreter services in the greatest number of clinical units incurred the highest costs (sites 1 and 2). Another high-cost site operated a bilingual nurse advice line within a call center serving a large population of Medicaid HMO members (site 3). These three sites had many more personnel and full-time equivalent interpreters involved in the HJ intervention than the other sites. The three hospital systems that focused on improving the availability of interpreters in a few high-volume clinical units (sites 4, 6, and 7) had fewer personnel and incurred lower costs. These cost findings can serve as a rough guideline for other similar health care organizations interested in implementing similar interventions in their communities.

\section{LESSONS LEARNED FROM HJ IMPLEMENTATION}

The case studies of the $\mathrm{HJ}$ sites were organized according to a framework suggested by a recent systematic review of the literature on adoption and diffusion of innovation in service organizations. ${ }^{19}$ We observed that there were a number of barriers and facilitators that, in part, explained some of the strengths and weaknesses we observed in the implementation of the HJ interventions in the various sites. We identified the following driving forces, barriers, and facilitators to implementation.

A Variety of Motivations Facilitate Change. Administrators, staff, and stakeholders at each of the HJ sites were asked to reflect on the primary motivations of the grantee and their partners, including internal and external forces for change. Most reported some combination of a growing Latino population with LEP in their catchment area, a sense of 
Table 1. Project Features of the Participating Sites and Estimated Annual Operating Costs in 2004 Dollars (Arranged in Descending Order of Costs)

\begin{tabular}{|c|c|c|c|c|c|c|c|c|c|c|c|}
\hline Site ID & $\begin{array}{l}\text { Grantee } \\
\text { organization }\end{array}$ & $\begin{array}{l}\text { Location } \\
\text { in census } \\
\text { region } \\
\text { (urban/ } \\
\text { rural) }\end{array}$ & $\begin{array}{l}\text { Demonstration } \\
\text { units }\end{array}$ & $\begin{array}{l}\text { Demo. } \\
\text { unit } \\
\text { patient } \\
\text { volume }\end{array}$ & $\begin{array}{l}\text { Latino } \\
(\%)\end{array}$ & $\begin{array}{l}\text { LEP (\%) } \\
\text { among } \\
\text { Latino }\end{array}$ & $\begin{array}{l}\text { Primary } \\
\text { interventions }\end{array}$ & $\begin{array}{l}\text { Training } \\
\text { intervention }\end{array}$ & $\begin{array}{l}\text { Persons } \\
\text { in } \\
\text { project }\end{array}$ & $\begin{array}{l}\text { Interpreter } \\
\text { FTE }\end{array}$ & $\begin{array}{l}\text { Estimated } \\
\text { annual } \\
\text { costs* }^{*}\end{array}$ \\
\hline Site_1 & $\begin{array}{l}\text { Hospital } \\
\text { system }\end{array}$ & $\begin{array}{l}\text { South } \\
\text { (mixed) }\end{array}$ & $\begin{array}{l}\text { A language } \\
\text { services } \\
\text { agency that } \\
\text { is partnering } \\
\text { with } 13 \\
\text { clinical units } \\
\text { in three } \\
\text { hospitals }\end{array}$ & $\mathrm{N} / \mathrm{A}$ & N/A & N/A & $\begin{array}{l}\text { Developed a new } \\
\text { language } \\
\text { services agency } \\
\text { providing on-site } \\
\text { and on-call } \\
\text { interpreters to } \\
\text { local hospitals }\end{array}$ & $\begin{array}{l}\text { College } \\
\text { certificate } \\
\text { (no credit) }\end{array}$ & 45 & 15.5 & $\$ 1,181,000$ \\
\hline Site_2 & $\begin{array}{l}\text { Medicaid } \\
\text { HMO }\end{array}$ & $\begin{array}{l}\text { Northeast } \\
\text { (urban) }\end{array}$ & $\begin{array}{l}\text { Health plan } \\
\text { partnering } \\
\text { with } 4 \\
\text { hospitals } \\
\text { involving } 6 \\
\text { clinical units } \\
\text { (ED, OB/ } \\
\text { GYN, urgent } \\
\text { care) }\end{array}$ & $\begin{array}{l}16,700 / \\
\text { mo. }\end{array}$ & $\begin{array}{l}2,500 / \\
\text { mo. } \\
(15 \%)\end{array}$ & $\begin{array}{l}700 / \\
\text { mo. } \\
(28 \%)\end{array}$ & $\begin{array}{l}\text { Provided } \\
\text { reimbursement } \\
\text { for medical } \\
\text { interpretation } \\
\text { and supported } \\
\text { development } \\
\text { of interpreter } \\
\text { programs in } \\
\text { partner } \\
\text { hospitals }\end{array}$ & $\begin{array}{l}\text { No educational } \\
\text { partner }\end{array}$ & 35 & 12.5 & $\$ 989,000$ \\
\hline Site_3 & $\begin{array}{l}\text { Medicaid } \\
\text { HMO }\end{array}$ & $\begin{array}{l}\text { West } \\
\text { (urban) }\end{array}$ & $\begin{array}{l}\text { A call } \\
\text { center to } \\
\text { serve } \\
\text { Spanish- } \\
\text { speaking } \\
\text { members } \\
\text { of health } \\
\text { plan }\end{array}$ & $81,000^{\dagger}$ & $\begin{array}{c}46,500^{\dagger} \\
(57 \%)\end{array}$ & $\begin{array}{c}34,000^{\dagger} \\
(73 \%)\end{array}$ & $\begin{array}{l}\text { Provided } 24 / 7 \\
\text { bilingual nurse } \\
\text { advice line } \\
\text { offering nurse } \\
\text { advice and } \\
\text { medical } \\
\text { interpretation }\end{array}$ & $\begin{array}{l}\text { Module for } \\
\text { medical school } \\
\text { “standardized } \\
\text { LEP patient } \\
\text { exam" and use } \\
\text { of interpreters }\end{array}$ & 34 & $6^{\ddagger}$ & $\$ 848,000$ \\
\hline Site_4 & $\begin{array}{l}\text { Hospital } \\
\text { system }\end{array}$ & $\begin{array}{l}\text { Northeast } \\
\text { (urban) }\end{array}$ & $\begin{array}{l}\text { Two hospital } \\
\text { EDs and one } \\
\text { hospital OB/ } \\
\text { GYN unit }\end{array}$ & $\begin{array}{l}8,200 / \\
\text { mo. }\end{array}$ & $\begin{array}{l}3,600 / \\
\text { mo. } \\
(44 \%)\end{array}$ & $\begin{array}{l}1,800 / \\
\text { mo. } \\
(50 \%)\end{array}$ & $\begin{array}{l}\text { Provided } \\
\text { dedicated, } \\
\text { dual role and } \\
\text { contracted } \\
\text { interpreters }\end{array}$ & $\begin{array}{l}\text { Graduate-level } \\
\text { interdisciplinary } \\
\text { seminar series } \\
\text { (no credit) }\end{array}$ & 9 & 4 & $\$ 561,000$ \\
\hline Site_5 & $\begin{array}{l}\text { Area Health } \\
\text { Education } \\
\text { Center }\end{array}$ & $\begin{array}{l}\text { Midwest } \\
\text { (rural) }\end{array}$ & $\begin{array}{l}\text { AHEC with a } \\
\text { video } \\
\text { interpreter } \\
\text { service } \\
\text { partnering } \\
\text { with five } \\
\text { hospitals and } \\
\text { two higher } \\
\text { education } \\
\text { institutions }\end{array}$ & $\mathrm{N} / \mathrm{A}$ & $\mathrm{N} / \mathrm{A}$ & N/A & $\begin{array}{l}\text { Provided video } \\
\text { medical } \\
\text { interpreters via } \\
\text { high speed } \\
\text { communication } \\
\text { links among } \\
\text { partnering } \\
\text { hospitals }\end{array}$ & $\begin{array}{l}\text { Community } \\
\text { college } \\
\text { certificate } \\
\text { (credit) }\end{array}$ & 13 & 3.25 & $\$ 534,000$ \\
\hline Site_6 & $\begin{array}{l}\text { Hospital } \\
\text { system }\end{array}$ & $\begin{array}{l}\text { South } \\
\text { (mixed) }\end{array}$ & $\begin{array}{l}\text { The entire } \\
\text { hospital } \\
\text { but focus } \\
\text { on OB/GYN } \\
\text { inpatients }\end{array}$ & $\begin{array}{l}1,400 / \\
\text { mo. }\end{array}$ & $\begin{array}{l}183 \\
(13 \%)\end{array}$ & $\begin{array}{l}165 \\
(90 \%)\end{array}$ & $\begin{array}{l}\text { Improved } \\
\text { availability of } \\
\text { interpreters to } \\
\text { match patient } \\
\text { demand }\end{array}$ & $\begin{array}{l}\text { College course } \\
\text { (credit) }\end{array}$ & 12 & 4 & $\$ 492,000$ \\
\hline Site_7 & $\begin{array}{l}\text { Hospital } \\
\text { system }\end{array}$ & $\begin{array}{l}\text { South } \\
\text { (urban) }\end{array}$ & $\begin{array}{l}\text { Two hospital } \\
\text { EDs and one } \\
\text { hospital OB/ } \\
\text { GYN unit }\end{array}$ & $\begin{array}{l}20,000 / \\
\text { mo. }\end{array}$ & $\begin{array}{l}1,900 / \\
\text { mo. } \\
(10 \%)\end{array}$ & $\begin{array}{l}1,600 / \\
\text { mo. } \\
(85 \%)\end{array}$ & $\begin{array}{l}\text { Improved } \\
\text { availability and } \\
\text { accessibility of } \\
\text { dedicated } \\
\text { medical } \\
\text { interpreters/ } \\
\text { patient } \\
\text { navigators }\end{array}$ & In development & 18 & 5.4 & $\$ 402,000$ \\
\hline Site_8 & $\begin{array}{l}\text { Community } \\
\text { organization }\end{array}$ & $\begin{array}{l}\text { West } \\
\text { (rural) }\end{array}$ & $\begin{array}{l}\text { The } \\
\text { community } \\
\text { organization }\end{array}$ & $\mathrm{N} / \mathrm{A}$ & $\mathrm{N} / \mathrm{A}$ & $\mathrm{N} / \mathrm{A}$ & $\begin{array}{l}\text { Worked to affect } \\
\text { state and service } \\
\text { provider policy } \\
\text { on language } \\
\text { access services, } \\
\text { assisted partner } \\
\text { organizations, } \\
\text { and provided } \\
\text { interpretation } \\
\text { for clients }\end{array}$ & $\begin{array}{l}\text { Community } \\
\text { college course } \\
\text { (no credit) }\end{array}$ & 13 & $\mathrm{~N} / \mathrm{A}$ & $\$ 324,000$ \\
\hline
\end{tabular}


Table 1. (continued)

\begin{tabular}{|c|c|c|c|c|c|c|c|c|c|}
\hline Site ID & $\begin{array}{l}\text { Grantee } \\
\text { organization }\end{array}$ & $\begin{array}{l}\text { Location } \\
\text { in census } \\
\text { region } \\
\text { (urban/ } \\
\text { rural) }\end{array}$ & $\begin{array}{l}\text { Demonstration } \\
\text { units }\end{array}$ & $\begin{array}{l}\text { Demo. } \\
\text { unit } \\
\text { patient } \\
\text { volume }\end{array}$ & $\begin{array}{l}\text { Latino } \\
(\%)\end{array}$ & $\begin{array}{l}\text { LEP (\%) } \\
\text { among } \\
\text { Latino }\end{array}$ & $\begin{array}{l}\text { Primary } \\
\text { interventions }\end{array}$ & $\begin{array}{l}\text { Training } \\
\text { intervention }\end{array}$ & $\begin{array}{lll}\text { Persons } & \text { Interpreter } & \text { Estimated } \\
\text { in } & \text { FTE } & \text { annual } \\
\text { project } & & \text { costs }^{*}\end{array}$ \\
\hline Site_9 & $\begin{array}{l}\text { Community } \\
\text { organization }\end{array}$ & $\begin{array}{l}\text { South } \\
\text { (mixed) }\end{array}$ & $\begin{array}{l}\text { A full-service } \\
\text { language } \\
\text { services } \\
\text { agency “for } \\
\text { hire" by } \\
\text { clinical } \\
\text { institutions }\end{array}$ & $\mathrm{N} / \mathrm{A}$ & $\mathrm{N} / \mathrm{A}$ & $\mathrm{N} / \mathrm{A}$ & $\begin{array}{l}\text { Created a } \\
\text { language } \\
\text { services agency } \\
\text { for interpreter } \\
\text { training and } \\
\text { supply }\end{array}$ & In development & Did not participate in cost study \\
\hline Site_10 & $\begin{array}{l}\text { School of } \\
\text { Public } \\
\text { Health }^{\S}\end{array}$ & $\begin{array}{l}\text { West } \\
\text { (urban) }\end{array}$ & $\begin{array}{l}\text { A School of } \\
\text { Public Health } \\
\text { partnering } \\
\text { with six } \\
\text { provider sites } \\
\text { for internship } \\
\text { rotation }\end{array}$ & $\mathrm{N} / \mathrm{A}$ & $\mathrm{N} / \mathrm{A}$ & $\mathrm{N} / \mathrm{A}$ & $\begin{array}{l}\text { Established a hea } \\
\text { and health appli } \\
\text { graduate-level p } \\
\text { internship (cred } \\
\text { Spanish health } \\
\text { materials }\end{array}$ & $\begin{array}{l}\text { lth interpreting } \\
\text { ed linguistics } \\
\text { rogram with } \\
\text { t) and developed } \\
\text { education }\end{array}$ & Did not participate in cost study \\
\hline
\end{tabular}

N/A = Not applicable, ED = emergency departments, OB/GYN = obstetric/gynecology, LEP = limited English proficiency, FTE = full-time equivalent

*The costs were operating costs in providing the primary interventions from October 2004 to September 2005 , valued by 2004 dollars.

${ }^{\dagger}$ Number of Medicaid HMO members in the service area.

"These are bilingual registered nurses providing nurse advice and medical interpretation. There were additional 3.75 FTE bilingual medical assistant receptionists transferring Latino members' calls to a bilingual nurse, as well as providing membership services to these members (e.g., verifying membership, scheduling appointment).

${ }^{\S}$ Because of conflicts that developed within the program, the site was dropped before the end of the national demonstration.

altruism that most health care organizations share, and concerns about the legal ramifications of ignoring either the Office of Civil Rights' guidance on Title $\mathrm{VI}^{16}$ or their own concerns about malpractice risks associated with language barriers. In only a few cases were sites responding to pressure from Latino advocacy organizations as many of their constituency were immigrants who did not feel empowered to demand better services.

Providers Need Convincing About the Quality Rationale. Whereas some projects spent much time cultivating and persuading administrators, the assumption was that the usefulness of the interpreters would be obvious to physicians and other health care providers. Most HJ project leaders assumed they would not need to convince physicians of the need to hire, support, and utilize qualified medical interpreters in their practice settings. Many believed that once they were able to assess, train, and certify interpreters as qualified, hospitals, clinics, physicians and nurses would immediately recognize the difference between a professionalized workforce and the ad hoc interpreters they had previously used (e.g., family, bilingual housekeeping staff). Whereas reports from administrators were mixed, front-line interpreters routinely told us that they faced an uphill struggle to integrate themselves into health care teams. Unfortunately, most of the project leaders realized too late in the intervention period that they had not sufficiently communicated to physicians the rationale for adoption of interpreter programs. None provided training to physicians on how to work with interpreters.

Implementation Strategies to Ensure Program Adoption are Critical. In many ways, at both the HJ national demonstration level and the local project level, there was a lack of attention to handling implementation within busy health care institutions.
Many physicians and nurses had become used to improvising and in busy and often chaotic settings (e.g., EDs) did not feel they could wait for an interpreter to be paged or to finish interpreting for another patient. Because coverage was not 24/ 7 in any of the sites, there were different procedures for accessing language services at different times of day. And in academic medical settings residents and other trainees work in rotations, meaning that new staff are constantly being introduced. Unfortunately, to the extent that HJ projects attempted to orient physicians and nurses to the new interpreter programs, they did so through in-service trainings at busy staff meetings rather than through the methods that the literature suggests are effective, such as directly involving physicians in the planning for the program design and implementation, and cultivating physician champions to foster behavior change.

Interpreter Proficiency Standards are Lacking. The HJ national demonstration put a spotlight on the need to develop comprehensive training programs for medical interpretation, and most $\mathrm{HJ}$ sites found educational partners and worked with them to develop credit or noncredit courses or certificates. However, many of the sites also sponsored 40-hour training using the Bridging the Gap curriculum. ${ }^{20}$ There was no agreement across sites as to how much training is appropriate and there are no universally accepted benchmarks by which to judge the proficiency of interpreters. Several HJ sites suggested that different levels of training may be required for interpreters depending on the nature of the communication being interpreted. For example, ad hoc interpreters may be adequate for helping patients navigate a health care facility whereas highly proficient interpreters are needed to interpret in clinical encounters. Sites participated in beta testing of a language proficiency examination but it received only mixed reviews. The field still lacks benchmarks and tools to measure proficiency. 
Uncertain Job Market for Trained Interpreters Threatens Sustainability. HJ projects spent time and resources attempting to professionalize the role of interpreter and create educational programs that will produce a steady stream of individuals qualified to provide medical interpretation services. The fact is, however, these are low-wage jobs with little in the way of a career ladder. Interpreters, especially the least experienced ones, struggled to gain respect from the health professionals with whom they worked. Some reported that their motivation to become an interpreter was intrinsic but whether such motivations will be enough to prevent high rates of turnover is questionable. Whether the educational programs initiated under the HJ grants will be able to sustain themselves depends on whether individuals are willing to pay for college (or graduate level training) to get a low-wage job. In a few instances, employers were willing to subsidize the costs of training. It remains an open question whether there will be sufficient demand for medical interpreters in local markets to sustain college-level training programs.

Physicians Tend to Avoid Tele-technology. Given the costs of in-person interpretation, some have suggested that technology is the only reasonable approach to providing language access services for large numbers of patients and/or across large institutions. However, physicians and nurses in the HJ sites preferred on-site interpreters and tended to avoid telephonic language lines and remote video-conferencing, even when attempts were made to make the technologies readily available and user-friendly.

The Business Case for Medical Interpretation is Difficult to Make. In spite of the Foundation's urging at the inception of the demonstration, most $\mathrm{HJ}$ sites had not developed a business case to sustain their interventions by the close of the demonstration. A few sites attempted but did not succeed in producing data to suggest that there were cost offsets related to medical interpretation. Most health care institutions that retained their interpreter programs at the end of the demonstration simply absorbed the ongoing operating costs. In the end, as suggested by health care CEO and CFOs with whom we spoke, a quality of care or risk management argument may be more feasible and successful in spurring health care providers and purchasers to provide language access services than an argument based on cost offsets.

Although HJ projects faced a number of barriers, their experience also suggests that there are a number of facilitators that can enhance the success of future efforts. Using the words of the project staff, administrators, and community stakeholders with whom we spoke, some of the lessons learned include the following:

- Health care organizations are hierarchical, therefore it is important to have active, vocal support at the highest levels of medical and administrative leadership in the organization;

- If there is little motivation for the issue of language access, it is important to connect it to one of the driving issues of the organization (e.g., patient safety, quality of care), to help gain momentum for the project;
- Projects that succeed involve good planning-taking time to consider all of the options rather than adopting a one size fits all model;

- Assuming that problems will arise in implementation of any innovation, projects that adopt a systematic approach to problem identification and trouble shooting are able to keep the project from being derailed;

- Prioritizing staff time devoted to efforts related to critical success factors is associated with smoother implementation;

- The local Latino community could become either a facilitator or a barrier to implementation; it is important that health care organizations collaborate with the local community rather than implement their own solutions without consultation;

- The most successful projects have leaders on the ground who have a vision for what they want to accomplish along with substantial business and interpersonal skills;

- Programs that are sustainable are those that are integrated into the normal operations and workflow of an organization from the outset-not grafted on as special projects; and

- Training was critical to implementation of language access services; if training is not a part of the mission of the organization, partnering with an experienced training organization is important.

\section{CONCLUSION}

The HJ national demonstration provides health care organizations many valuable lessons regarding the provision or enhancement of language access services. First, there are a variety of creative models that can be employed to develop, enhance, and sustain language access services. Second, there are considerable operating costs to consider and the scale of implementation is the main cost driver. The ultimate costs and benefits of these language service programs depend on how they are implemented. The most common lesson drawn from the evaluation was the extent to which the HJ sites underestimated the difficulty of changing the culture of health care organizations, and the lack of attention they paid to the role that physicians play (or could have played) in the adoption of innovative language services. Other challenges to be resolved are the need for benchmarks and tools to measure the proficiency of interpreters, and the creation of a sustainable market environment for professional, college-level interpreter educational programs.

Implementing innovative programs in health care organizations takes resources, leadership, and implementation strategies. We hope the lessons learned from the HJ evaluation will be useful to policymakers and health care providers across the country as they take steps to overcome language barriers to serve a growing and dispersed immigrant population.

Acknowledgements: The authors would like to acknowledge the valuable guidance and assistance of our colleagues at the RWJFDebra J. Pérez PhD, Laura C. Leviton PhD, and Pam S. Dickson MBAand Yolanda Partida MSW, DPA of the HJ NPO at the UCSF Fresno Center for Medical Education \& Research. We also express our profound gratitude to the principal investigators, staff, and community stakeholders at the ten HJ demonstration sites; without whom the evaluation would not have been possible. Finally, we thank Diane Schoeff and Sophia Washam for their assistance with data collection, and Yuyan Shi for her assistance with data analysis. This work was supported by grants from the RWJF. 
Conflict of Interest: None of the authors of this paper have employment or consulting relationships, or investment income from any of the for-profit or nonprofit organizations that are the subject of this research.

Corresponding Author: Leo S. Morales, MD, PhD; Division of General Internal Medicine and Health Services Research, Department of Medicine David Geffen School of Medicine at the University of California, Los Angeles, CA, USA (e-mail: lsmorales@mednet.ucla.edu).

\section{REFERENCES}

1. Bureau of the Census. We the American Foreign Born. Retrieved September 20, 2006, from http://www.census.gov/apsd/wepeople/we7.pdf.

2. Bureau of the Census. The Foreign Born Population: 2000. Retrieved September 20, 2006, from http://www.census.gov/prod/2003pubs/ c2kbr-34.pdf.

3. Bureau of the Census. The Hispanic Population: 2000. Retrieved September 20, 2006, from http://www.census.gov/prod/2001pubs/ c2kbr01-3.pdf.

4. National Research Council. Hispanics and the future of America. In: Tienda Marta, Mitchell Faith, eds. Panel on Hispanics in the United States. Committee on Population, Division of Behavioral and Social Sciences and Education. Washington DC: The National Academies Press; 2006.

5. Kirkman-Liff B, Mondragón D. Language of interview: relevance for research of southwest Hispanics. Am J Public Health. 1991;81:1399-404.

6. Hu DJ, Covell RM. Health care usage by Hispanic outpatients as a function of primary language. West J Med. 1986;155:490-3.

7. Weinick RM, Krauss NA. Racial/ethnic differences in children's access to care. Am J Public Health. 2000;90:1771-4.

8. Marks G, Solis J, Richardson JL, Collins LM, Birba L, Hisserich J. Health behavior of elderly Hispanic women: does cultural assimilation make a difference? Am J Public Health. 1987;77:1315-9.
9. Woloshin S, Bickell NA, Schwartz LM, Gany F, Welch HG. Language barriers in medicine in the United States. J Am Med Assoc. 1995;273 (9):724-8.

10. Gandhi TK, Burstin HR, Cook EF, et al. Drug complications in outpatients. J Gen Intern Med. 2000;15:149-54.

11. Hampers LC, Cha S, Gutglass DJ, Binns HJ, Krug SE. Language barriers and resource utilization in a pediatric emergency department. Pediatrics. 1999; 103:1253-6.

12. Morales LS, Elliott M, Weech-Maldonado R, Hays RD. The impact of interpreters on parents' experiences with ambulatory care for their children. Med Care Res Rev. 2006;63(1):110-28 (Feb).

13. Weech-Maldonado R, Morales LS, Elliott M, Spritzer K, Marshall G, Hays RD. Race/ethnicity, language, and patients' assessments of care in Medicaid managed care. Health Serv Res. 2003;38(3):789-808 (Jun).

14. Morales LS, Cunningham WE, Brown JA, Liu H, Hays RD. Are Latinos less satisfied with communication by health care providers? J Gen Intern Med. 1999;14(7):409-17 (Jul).

15. Flores G. The impact of medical interpreter services on the quality of health care: a systematic review. Med Care Res Rev. 2005;62(3):255-99 (Jun).

16. Office of Civil Rights, U.S. Department of Health and Human Services. Guidance Memorandum, January 29, 1998, Title VI Prohibition Against National Origin Discrimination-Persons With Limited English Proficiency. Retrieved September 20, 2006, from http://www.hhs.gov/ocr/ lepfinal.htm

17. Jacobs E, Chen AH, Karliner LS, Agger-Gupta N, Mutha S. The need for more research on language barriers in health care: a proposed research agenda. Milbank Q. 2006;84(1):111-33.

18. Morales LS, Ridgely MS, Escarce JJ, Avila C, Garcia RE, Setodji C, Wu s. Language Access Services for Latinos with Limited English Proficiency: The National Evaluation of Hablamos Juntos, Final Report. Princeton, NJ: Robert Wood Johnson Foundation, March 2007

19. Greenhalgh T, Robert G, Macfarlane F, Batte $\mathbf{P}$, Kyriakidou $\mathbf{O}$. Diffusion of innovations in service organizations: systematic review and recommendations. Milbank Q. 2004;82(4):581-629.

20. Cross Cultural Health Care Program. Interpreter Training Programs. Retrieved July 6, 2007, from http://www.xculture.org/training/ overview/interpreter/programs.html. 